\title{
A Glimmer of Hope: Recent Updates and Future Challenges in Zika Vaccine Development
}

\author{
Priscila M. S. Castanha $₫$ and Ernesto T. A. Marques * \\ Graduate School of Public Health, Department of Infectious Diseases and Microbiology, University of Pittsburgh, \\ Pittsburgh, PA 15261, USA; pmd35@pitt.edu \\ * Correspondence: marques@pitt.edu \\ Academic Editor: Luis Martinez-Sobrido

Received: 1 October 2020; Accepted: 26 November 2020; Published: 30 November 2020

\begin{abstract}
The emergence and rapid spread of Zika virus (ZIKV) on a global scale as well as the establishment of a causal link between Zika infection and congenital syndrome and neurological disorders triggered unprecedented efforts towards the development of a safe and effective Zika vaccine. Multiple vaccine platforms, including purified inactivated virus, nucleic acid vaccines, live-attenuated vaccines, and viral-vectored vaccines, have advanced to human clinical trials. In this review, we discuss the recent advances in the field of Zika vaccine development and the challenges for future clinical efficacy trials. We provide a brief overview on Zika vaccine platforms in the pipeline before summarizing the vaccine candidates in clinical trials, with a focus on recent, promising results from vaccine candidates that completed phase I trials. Despite low levels of transmission during recent years, ZIKV has become endemic in the Americas and the potential of large Zika outbreaks remains real. It is important for vaccine developers to continue developing their Zika vaccines, so that a potential vaccine is ready for deployment and clinical efficacy trials when the next ZIKV outbreak occurs.
\end{abstract}

Keywords: Zika virus; vaccine candidates; vaccine platforms; clinical trials

\section{Introduction}

Zika virus (ZIKV), a member of the Flaviviridae family (Flavivirus genus), is a positive, single-stranded, enveloped RNA virus primarily transmitted to humans through the bite of infected Aedes aegypti mosquitoes [1,2]. ZIKV was initially isolated in 1947 as part of routine surveillance investigations of the yellow fever transmission cycle carried out by the Rockefeller Institute in the Zika forest of Uganda [1]. During the 50 years following its discovery, only few sporadic Zika cases associated with mild, self-limiting febrile disease were detected in humans in Africa and in some Asian countries [3-5]. The first large outbreak of Zika disease in humans was documented in 2007 on the Pacific Island of Yap, Federated States of Micronesia [6]. Seven years later, additional ZIKV outbreaks in humans were also registered on other Pacific Islands, including French Polynesia [7-9]. In early 2015, a large outbreak of Zika disease was registered in Brazil [10-12] and ZIKV spread rapidly throughout the Americas [13,14]. Until then, ZIKV disease was considered a benign viral infection with minor health consequences, but a causal link between ZIKV infection and clusters of microcephaly and neurological disorders was later recognized [15-17], leading the WHO to declare the ZIKV outbreak as a Public Health Emergency of International Concern in February 2016 [18].

Much has been learned during the ZIKV outbreak in the Americas. Multiple, previously unknown routes of human-to-human ZIKV transmission have been identified, including via sexual [19-24], intrauterine, and intrapartum transmission [16,17,25-31], and via blood transfusion [8,32,33]. Evidence from epidemiological studies has also shown that ZIKV infection sporadically triggers Guillain-Barré syndrome, a rare but serious autoimmune-mediated attack of healthy peripheral neurons and glial 
cells, leading to ascending paralysis and polyneuropathy and a small number of cases of confirmed viral encephalitis. Cases of ZIKV-associated Guillain-Barré syndrome have been reported in Brazil, Colombia, French Polynesia, and several other countries [34-40]. However, perhaps the most dramatic ZIKV feature discovered during the Americas outbreak has been the impact of ZIKV infections on pregnant women and their infants. Fetal microcephaly linked to Zika infections during pregnancy was first reported in Brazil $[16,17,29,31]$. Later, Zika-related microcephaly was also identified in other South and Central American countries, and in retrospective analyses of the French Polynesia outbreak [41-46]. Other Zika-associated congenital disorders have also been identified and include intrauterine growth restriction, fetal demise, cerebral calcifications, sensorineural hearing loss, visual impairment $[26,28,30,47-50]$, and delayed cognitive development. However, the full spectrum of clinical presentations of congenital Zika syndrome is yet to be described.

Intense research efforts on the underlying pathogenic mechanisms of Zika infections have also been made during the 2015-2016 Zika outbreak. Within a relatively short period of time, models of Zika disease and pathogenesis in mice and non-human primates have been established, including using female pregnant animals (reviewed in [51]). These studies have revealed ZIKV tropism to maternal and fetal tissues, including a broad range of placental cell types and the developing fetal human brain [25-27,52-54]. Prolonged persistence of ZIKV genome in several body tissues and fluids, including the male and female reproductive tract, has also been identified $[25,55,56]$. The close antigenic relationship that results in considerable serological cross-reactivity between ZIKV and other flaviviruses, particularly dengue viruses (DENV), has also been a topic of intense research. The fact that poorly neutralizing cross-reactive antibodies can potentially mediate antibody-dependent enhancement (ADE) of Zika or dengue infections has been extensively explored using in vitro and ex vivo experimental approaches, animal models, and epidemiological analyses [57-65]. Antibody responses to DENV have been shown to be highly cross-reactive to ZIKV and vice-versa. In fact, several analyses have shown that these Zika and dengue cross-reactive antibodies are able to promote either enhancement of or protection against subsequent flavivirus infections, an effect that seems to depend on the antibody levels at the time of infection [57-59]. However, it is still unknown how these Zika and dengue antibody interactions will impact future vaccination efforts.

All the aforementioned aspects of the recent Zika outbreaks highlight the urge for the development of a safe and effective vaccine against Zika. Since 2016, a number of candidates using multiple vaccine platforms have been developed and have shown promising results in preclinical testing. In this review, we discuss the advances in the development of these vaccines. Recent results of phase I clinical trials on Zika vaccine candidates are summarized and discussed. In addition, we address important remaining challenges for the clinical development and future deployment of Zika vaccines.

\section{Zika Virus Vaccine Development}

The emergence and rapid spread of Zika virus throughout the Americas in 2015 as well as the establishment of causal link between Zika infection and congenital syndrome and neurological disorders triggered unprecedented efforts towards the development of a Zika vaccine. Over the past 5 years, multiple vaccine platform technologies have been used in the design of vaccine prototypes (Figure 1), and 20 are currently in clinical evaluation in humans (Table 1). The accelerated development of multiple Zika vaccine candidates have benefited from over three decades of extensive research on flavivirus immunity, flavivirus vaccine studies, and the quick response of the research community in generating knowledge on Zika biology, pathogenesis, and animal models.

The use of traditional methods, such as the production of empirical, live-attenuated vaccines by repeated passages of virus in cell culture or in animals, or conventional viral inactivation methods have been proven efficacious for the development of multiple flavivirus vaccines. Safe and efficacious vaccines for the prophylaxis of yellow fever virus (YFV), tick-borne encephalitis virus (TBEV) and Japanese encephalitis virus (JEV) have been administered to human populations (reviewed at [66]). The live-attenuated YFV 17D vaccine has been shown to be highly effective and is currently administered 
to individuals aged 9 months or older, living in or traveling to endemic countries. This vaccine has led to significant reduction in the number of cases and deaths by YFV in the past 80 years. Another licensed, live-attenuated vaccine based on the SA 14-14-2 strain of the JEV has also been extensively used in China and other Asian countries to protect against infections by JEV in children and adults. Inactivated vaccines are also available to prevent JEV and TBEV-induced disease in endemic countries and have been shown to be safe and to engender protection. In addition to these traditional vaccine approaches, a JEV-YFV chimera vaccine developed using innovative molecular biology clone technologies for viral attenuation has been licensed for use in humans. A single dose of this chimera JEV-YFV vaccine has been shown to be safe and to induce sustained antibody responses in clinical trials. In addition, the vast experience in the development of tetravalent DENV vaccines [67] has also contributed to the development of Zika vaccines. There is one DENV vaccine approved for use in several countries (Sanofi-Dengvaxia) that is based on YFV/DENV chimeras. However, the deployment of this vaccine requires confirmation of a previous DENV infection prior to immunization [68]. Other dengue vaccine candidates include a vaccine based on chimeras with an attenuated DENV-2 strain (Takeda-TDV) that have completed a phase III trial, and a vaccine based on a 30-nucleotide deletion in the $3^{\prime}$ untranslated region (UTR) to reduce the efficiency of the viral replication, which is currently concluding its phase III trial in Brazil (Butantan-TDV).

To date, there is no single approved therapeutic or vaccine against Zika, but lessons from these positive stories in flavivirus vaccinology has prompted optimism in the development of Zika vaccines. The WHO vaccine development technology roadmap lays out two priority scenarios for Zika vaccine deployment: epidemic and endemic uses [69]. Despite low levels of transmission during recent years, ZIKV has become endemic in the Americas and the threat of large Zika outbreaks remains. Mass Zika vaccination targeting pregnant women and women of childbearing age populations during outbreaks would likely prevent prenatal Zika infection and thus congenital Zika syndrome cases. In the case of endemic usage, routine Zika immunization of children and adults living in or traveling to endemic countries would allow the establishment of population immunity and aid the prevention of both prenatal Zika infection in pregnant women and other Zika-related neurological complications in adults.

A

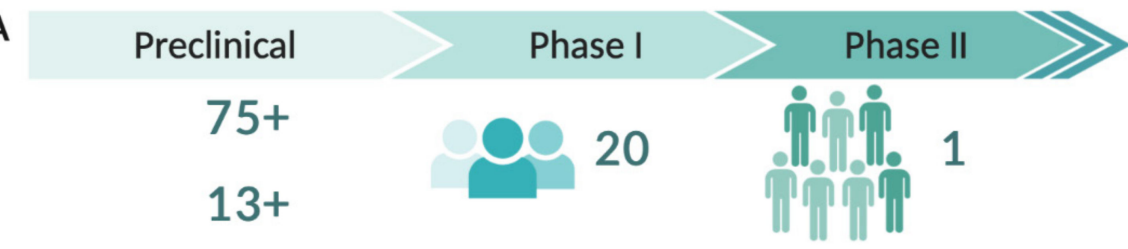

B

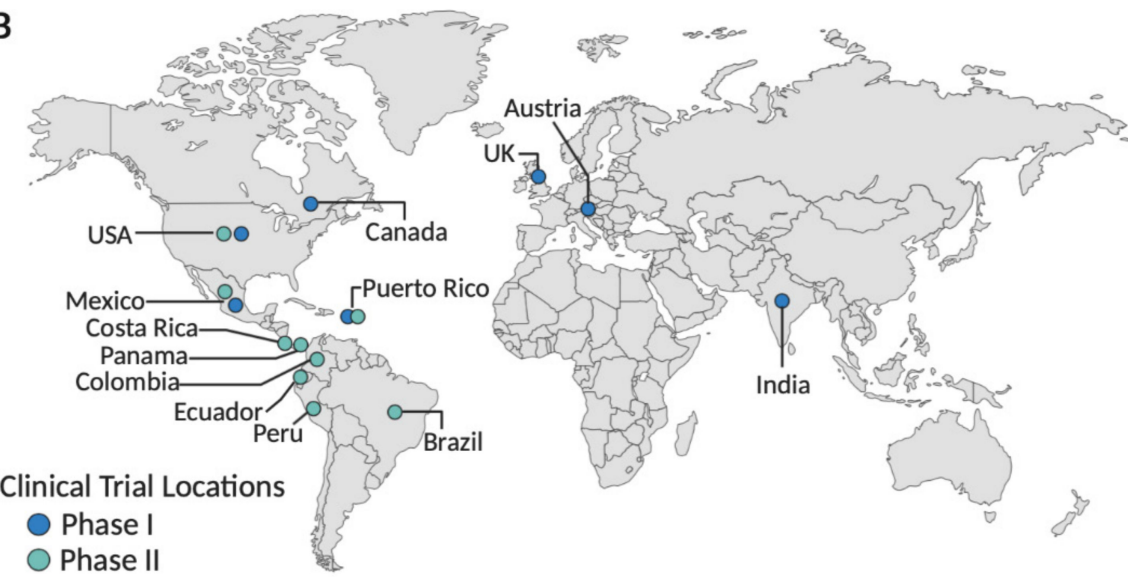

Figure 1. Zika vaccine development. (A) Number of Zika vaccine candidates tested in preclinical studies using mice models and non-human primates, and in phase I and II clinical trials in humans; (B) phase I and II clinical trial sites. Created with BioRender.com. 
Table 1. Zika vaccine candidates in clinical trials.

\begin{tabular}{|c|c|c|c|c|}
\hline Vaccine Platform & Vaccine Name & Developer(s) & Study Description/Current Status & Clinical Trial \\
\hline \multirow{7}{*}{$\begin{array}{l}\text { Purified } \\
\text { Inactivated } \\
\text { Vaccines }\end{array}$} & \multirow{4}{*}{$\begin{array}{l}\text { Zika Virus Purified } \\
\text { Inactivated Vaccine } \\
\quad \text { (ZPIV) }\end{array}$} & \multirow{4}{*}{ NIAID, WRAIR, BIDMC } & $\begin{array}{l}\text { Phase I trial on the safety, reactogenicity and immunogenicity, } \\
\text { and comparison of different doses and schedules of ZPIV in healthy, } \\
\text { flavivirus-naïve adult individuals-Completed }\end{array}$ & NCT02937233 \\
\hline & & & $\begin{array}{l}\text { Phase I trial on the safety, reactogenicity and immunogenicity of a higher } \\
\text { ZPIV dose in healthy, flavivirus-naïve adult individuals-Completed }\end{array}$ & NCT02952833 \\
\hline & & & $\begin{array}{l}\text { Phase I trial on the safety, reactogenicity and immunogenicity of two doses } \\
\text { of ZPIV and a late ZPIV boost in healthy, flavivirus-naïve adult } \\
\text { individuals-Completed }\end{array}$ & NCT02963909 \\
\hline & & & $\begin{array}{l}\text { Phase I trial on the safety, reactogenicity and immunogenicity of two doses } \\
\text { of ZPIV in healthy adults residing in a flavivirus endemic area-Active, } \\
\text { not recruiting }\end{array}$ & NCT03008122 \\
\hline & $\begin{array}{l}\text { Purified Inactivated Zika } \\
\text { Virus Vaccine (PIZV) }\end{array}$ & Takeda & $\begin{array}{l}\text { Phase I trial on the safety, immunogenicity and dose ranging of PIZV in } \\
\text { flavivirus-naïve and primed healthy adults-Active, not recruiting }\end{array}$ & NCT03343626 \\
\hline & VLA1601 & $\begin{array}{l}\text { Valneva Austria GmbH, } \\
\text { Emergent BioSolutions }\end{array}$ & $\begin{array}{l}\text { Phase I trial on the safety and immunogenicity of two dose levels of the } \\
\text { VLA1601 vaccine in healthy, flavivirus-naïve adults-Completed }\end{array}$ & NCT03425149 \\
\hline & BBV121 & $\begin{array}{l}\text { Bharat Biotech International } \\
\text { Limited }\end{array}$ & $\begin{array}{l}\text { Phase I trial to evaluate two doses of three sequentially escalating cohort of } \\
\text { BBV121 in healthy adult dengue seronegative and dengue seropositive } \\
\text { volunteers-Completed }\end{array}$ & NCT04478656 \\
\hline \multirow{5}{*}{ DNA Vaccines } & \multirow{2}{*}{$\begin{array}{l}\text { VRC5288 (Zika virus and } \\
\text { Japanese encephalitis } \\
\text { virus chimera) } \\
\text { VRC5283 (wild-type } \\
\text { Zika virus) }\end{array}$} & \multirow[t]{2}{*}{ NIAID, VRC } & $\begin{array}{l}\text { Phase I trial on the safety and immunogenicity of VRC5283 administered } \\
\text { via needle and syringe or needle-free injector in healthy } \\
\text { adults-Completed }\end{array}$ & NCT02996461 \\
\hline & & & $\begin{array}{l}\text { Phase I/Ib trial on the safety, tolerability, and immunogenicity of VRC5288 } \\
\text { administered via needle and syringe in healthy adults-Completed }\end{array}$ & NCT02840487 \\
\hline & $\begin{array}{l}\text { VRC5283 (wild-type } \\
\text { Zika virus) }\end{array}$ & $\begin{array}{c}\text { NIAID, VRC, Emmes } \\
\text { Company, } \\
\text { Leidos Biomedical Research, } \\
\text { FHI Clinical, } \\
\text { PPD }\end{array}$ & $\begin{array}{l}\text { Phase II/IIb trial on the safety, immunogenicity, and efficacy of a three-dose } \\
\text { vaccination regimen of the VRC5283 administered via needle-free device in } \\
\text { healthy adults and adolescents residing in flavivirus endemic and } \\
\text { nonendemic areas-Completed }\end{array}$ & NCT03110770 \\
\hline & \multirow[t]{2}{*}{ GLS-5700 } & \multirow[t]{2}{*}{$\begin{array}{l}\text { GeneOne Life Science, Inc., } \\
\text { Inovio Pharmaceuticals }\end{array}$} & $\begin{array}{l}\text { Phase I trial, dose-ranging study to evaluate the safety, tolerability, } \\
\text { and immunogenicity of GLS- } 5700 \text { in healthy, dengue-naïve } \\
\text { adults-Completed }\end{array}$ & NCT02809443 \\
\hline & & & $\begin{array}{l}\text { Phase I trial to evaluate the safety, tolerability, and immunogenicity of } \\
\text { GLS-5700 in dengue-seropositive adults-Completed }\end{array}$ & NCT02887482 \\
\hline
\end{tabular}


Table 1. Cont.

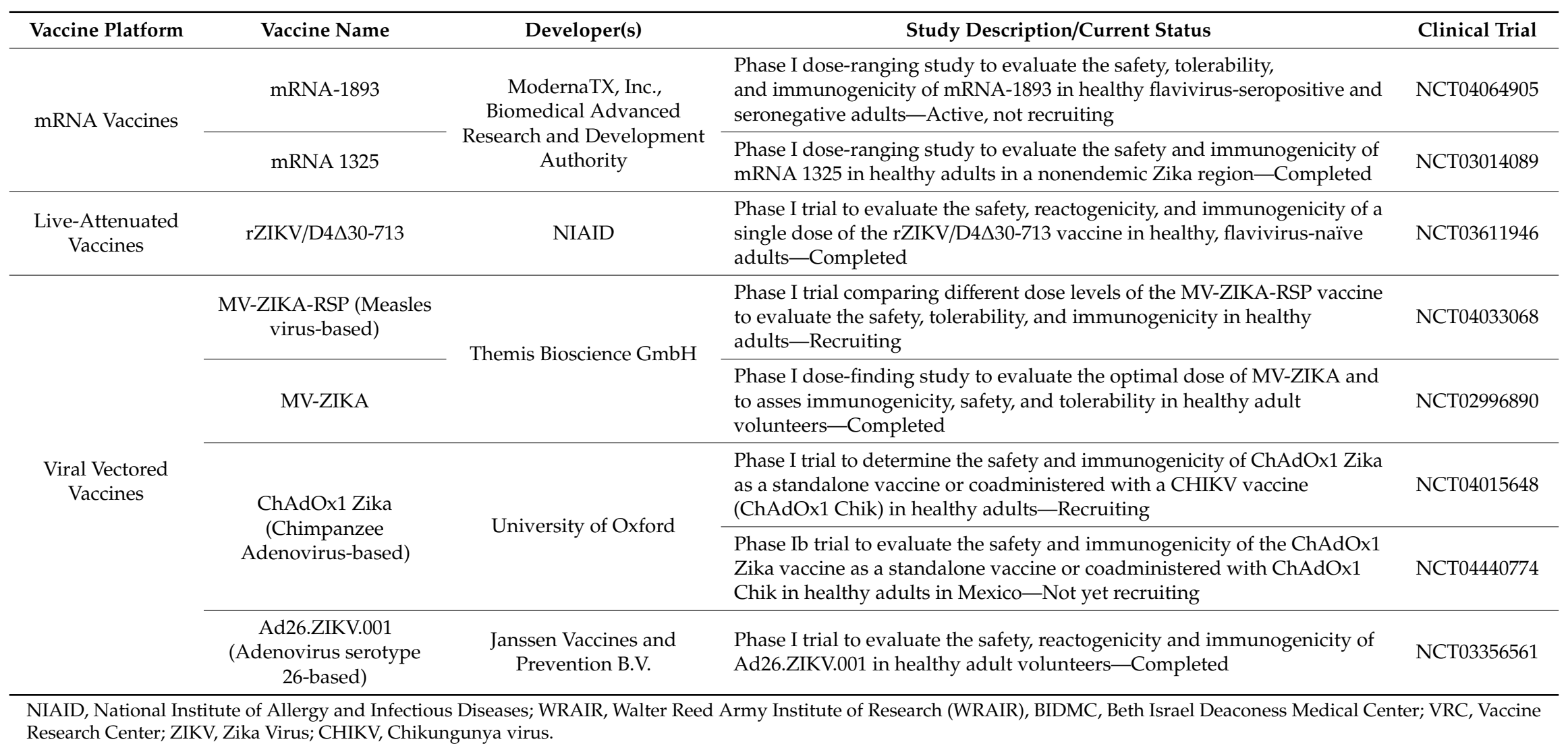


Numerous Zika vaccine platforms have been developed and tested in preclinical and clinical studies. These vaccines include classical vaccine designs (inactivated virus vaccines and live-attenuated vaccines) and novel vaccine technologies (viral-vectored vaccines and nucleic acid vaccines). Whole, inactivated viruses are prepared by exposing virus particles to chemical agents or heat. Virion then becomes noninfectious and thus unable to cause disease [70]. Live-attenuated vaccine approaches can be developed by different methods to attenuate virions until the virus effectively loses its pathogenic properties. These classical vaccine approaches have been proven to be safe and cost-effective, but they also have some disadvantages. Inactivated vaccines are considered safer than live vaccines, thus potentially offering a higher chance of being used by high-priority groups, such as pregnant women. However, chemical inactivation can alter the molecular structure of antigens and thereby negatively influence vaccine immunogenicity. In addition, inactivated vaccines usually require the use of adjuvants to stimulate robust immune responses. On the other hand, live-attenuated vaccines usually induce a more potent immune response than inactivated vaccines, as they induce innate responses as well as B- and T-cell responses against structural and nonstructural antigens, affording vaccinated individuals with long-term protection. However, live-attenuated vaccines are not administered to individuals with weakened immune systems and their use is also not recommended in pregnant populations unless their benefits outweigh the risks associated with vaccination [70,71]. Platforms such as Virus-like Particles (VLPs) have also been developed as an alternative to classical vaccine designs. VLP-based vaccines are nonreplicating structures composed of viral structural proteins that resemble virions. This vaccine strategy is considered safer than live-attenuated and inactivated virus vaccine approaches since the potential for reversion to virulence and incomplete inactivation are eliminated. Recent preclinical data have shown that VLP-based vaccine candidates elicit strong neutralizing antibody responses in mice [72-74]. Specifically, VLPs displaying the third domain (DIII) of the ZIKV envelop (E) protein were able to elicit antibodies that neutralize ZIKV without enhancing DENV infection in vitro [72,73]. If results are confirmed in larger animal models, this vaccine platform might constitute a good candidate for further clinical trials in humans.

Viral-vectored and nucleic acid vaccines are developed based on the coding sequence information of the viral genome alone through genetic engineering techniques [71]. With the aid of recombinant DNA techniques, nucleic acid and viral vectors are engineered to express the antigens of interest. Replication-deficient forms of this vaccine design are safe and relatively stable. Viral-vectored vaccines produce protein antigens endogenously and thus induce potent humoral and cellular immune responses. One disadvantage of this approach is the potential to induce antivector immunity, potentially reducing the immunogenicity of later inoculations using the same viral vector. DNA and mRNA vaccines are based on the delivery of gene coding specific antigens. Following uptake into cells, DNA constructs are transcribed and translated into target proteins by host cells. Constructs of mRNA work in a similar manner, but bypass the transcription step [75]. Nucleic acid vaccine designs can induce potent humoral and cellular responses, especially when the antigens are engineered to target the MHCII processing compartment [76,77], but one limitation of this approach is the limited efficiency of cellular uptake of nucleic acids. Often, nucleic acid vaccines require additional delivery devices to facilitate nucleic acid entry into cells [71,75]. To date, approximately 90 studies have been published reporting data on preclinical testing of Zika vaccine candidates using mice and non-human primate models (Figure 1). Several of these vaccine approaches showed promising results in animal models and advanced to clinical trials in humans.

\section{Zika Virus Vaccines Candidates in Clinical Trials}

As of September 2020, 20 phase I clinical trials have been registered in the clinicaltrials.gov platform (Table 1). Of those, eight phase I clinical trials have their interim or final results published in peer-reviewed journals (Table 2). So far, only one vaccine has advanced to phase II trials. The vast majority of the phase I trials were carried out in nonendemic areas of the United States and Europe. Four phase I clinical trials were conducted in Puerto Rico, an area with active Zika virus transmission. Phase II clinical trial sites include endemic and nonendemic areas of Zika transmission, including several sites in Latin America (Figure 1). 
Table 2. Zika vaccine candidates with results of their phase I clinical trials published in peer-reviewed journals.

\begin{tabular}{|c|c|c|c|c|c|c|}
\hline Vaccine Platform & Name/Sponsor & Antigen & Regimen (Dosage, Intervals, Route) & Study Design & Subject Characteristics & $\begin{array}{c}\text { Clinical } \\
\text { Trial/Reference }\end{array}$ \\
\hline \multirow{3}{*}{$\begin{array}{c}\text { Purified } \\
\text { Inactivated Virus }\end{array}$} & $\begin{array}{l}\text { PIZV or TAK- } 426 \\
\text { Takeda } \\
\text { Pharmaceuticals }\end{array}$ & $\begin{array}{c}\text { Whole Virus, } \\
\text { PRVABC59 } \\
\text { strain/Aluminum } \\
\text { hydroxide adjuvant }\end{array}$ & $\begin{array}{ll}- & 2,5 \text { or } 10 \mu \mathrm{g} \\
\text { - } & 0-4 \text { week } \\
\text { - } & \text { Deltoid, IM }\end{array}$ & $\begin{array}{l}\text { Multicenter, } \\
\text { randomized, } \\
\text { observer-blind, } \\
\text { placebo-controlled }\end{array}$ & $\begin{array}{ll}\text { - } & \text { Healthy adults, } \\
& \text { aged } 18-49 \text { years } \\
\text { - } & n=271 \text { participants } \\
\text { - } & \text { Two groups: flavivirus-naïve } \\
& (n=125) \text { and } \\
\text { flavivirus-primed }(n=146)\end{array}$ & $\begin{array}{l}\text { NCT03343626 } \\
\text { [78] }\end{array}$ \\
\hline & \multirow{2}{*}{$\begin{array}{c}\text { ZPIV } \\
\text { NIAID, WRAIR, } \\
\text { BIDMC }\end{array}$} & \multirow{2}{*}{$\begin{array}{c}\text { Whole Virus, } \\
\text { PRVABC59 } \\
\text { strain/Aluminum } \\
\text { hydroxide adjuvant }\end{array}$} & $\begin{array}{ll}- & 5 \mu \mathrm{g} \\
- & \text { Three intervals: } \\
\text { - } & 0-2 ; 0-4 \text { week; or single dose } \\
\text { - } & \text { Deltoid, IM }\end{array}$ & $\begin{array}{l}\text { Single-center, } \\
\text { randomized, } \\
\text { double-blind, } \\
\text { placebo-controlled }\end{array}$ & $\begin{array}{ll} & \text { Healthy adults, } \\
\text { - } & \text { aged } 18-50 \text { years } \\
\text { - } & \text { No known participants } \\
\text { previous flavivirus infection } \\
\text { or vaccination }\end{array}$ & $\begin{array}{l}\text { NCT02937233 } \\
\text { [79] }\end{array}$ \\
\hline & & & $\begin{array}{ll}- & 5 \mu \mathrm{g} \\
- & 0-4 \text { week } \\
\text { - } & \text { Deltoid, IM }\end{array}$ & $\begin{array}{l}\text { Single-center (three } \\
\text { independent trials), } \\
\text { randomized, } \\
\text { double-blind, } \\
\text { placebo-controlled }\end{array}$ & $\begin{array}{ll}\text { - } & \text { Healthy adults, } \\
& \text { aged } 18-49 \text { years } \\
\text { - } & n=67 \text { participants } \\
\text { - } & \text { No known history of } \\
& \text { previous flavivirus infection } \\
\text { or vaccination }\end{array}$ & $\begin{array}{l}\text { NCT02963909 } \\
\text { NCT02952833 } \\
\text { NCT02937233 } \\
{[80]}\end{array}$ \\
\hline \multirow[t]{2}{*}{ DNA Vaccine } & $\begin{array}{l}\text { VRC5288 and } \\
\text { VRC5283 } \\
\text { NIAID/VRC }\end{array}$ & $\begin{array}{l}\text { prM and E } \\
\text { VRC5288 (ZIKV and } \\
\text { JEV chimera) } \\
\text { VRC5283 (wild-type } \\
\text { ZIKV) }\end{array}$ & $\begin{array}{ll}\text { - } & 4 \mathrm{mg} \\
\text { - } & \text { VRC5288 } \\
\text { - } & 0-8,0-12 ; 0-4-8 ; \text { or } 0-4-20 \text { week } \\
\text { - } & \text { Deltoid, IM (needle and syringe) } \\
\text { - } & \text { VRC5283 } \\
\text { - } & 0-4-8 \text { week } \\
\text { - } & \text { Deltoid, IM (Single or Split-dose } \\
& \text { needle and syringe or needle-free } \\
& \text { with Stratis device) }\end{array}$ & $\begin{array}{l}\text { Two independent } \\
\text { trials (VRC 319, } \\
\text { multicenter; and } \\
\text { VRC320, } \\
\text { single-center), } \\
\text { randomized, } \\
\text { open-label }\end{array}$ & $\begin{array}{ll}\text { - } & \text { VRC } 319 \text { (VRC5288 vaccine) } \\
\text { - } & \text { Healthy adults, } \\
& \text { aged } 18-35 \text { years } \\
\text { - } & n=80 \text { participants } \\
\text { - } & \text { VRC } 320 \text { (VRC5283 vaccine) } \\
\text { - } & \text { Healthy adults, } \\
& \text { aged } 18-50 \text { years } \\
\text { - } & n=45 \text { participants }\end{array}$ & $\begin{array}{l}\text { NCT02840487 } \\
\text { NCT02996461 } \\
{[81]}\end{array}$ \\
\hline & $\begin{array}{c}\text { GLS-5700 } \\
\text { GeneOne Life } \\
\text { Science, Inc., Inovio } \\
\text { Pharmaceuticals }\end{array}$ & prM and $\mathrm{E}$ & $\begin{array}{ll}\text { - } & 1 \text { or } 2 \mathrm{mg} \\
\text { - } & 0-4-12 \text { week } \\
\text { - } & \text { Deltoid, IM followed by } \\
& \text { electroporation (CELLECTRA-3P) }\end{array}$ & $\begin{array}{l}\text { Multicenter, } \\
\text { nonrandomized, } \\
\text { open-label, } \\
\text { placebo-controlled }\end{array}$ & $\begin{array}{ll}\text { - } & \text { Healthy adults, } \\
& \text { aged } 18-65 \text { years } \\
\text { - } & n=40 \text { participants } \\
\text { - } & \text { Dengue-seronegative }\end{array}$ & $\begin{array}{l}\text { NCT02809443 } \\
\text { [82] }\end{array}$ \\
\hline
\end{tabular}

NIAID, National Institute of Allergy and Infectious Diseases; WRAIR, Walter Reed Army Institute of Research (WRAIR), BIDMC, Beth Israel Deaconess Medical Center; VRC, Vaccine

Research Center; ZIKV, Zika Virus; JEV, Japanese Encephalitis Virus; IM, intramuscular. 


\subsection{DNA Vaccines}

Three different Zika DNA vaccines have entered phase I clinical trials (Table 1). The first report of a Zika vaccine candidate in phase I clinical trial was published in 2017 (NCT02809443) [82], only 2 years after the first Zika outbreak in Latin America. This open label clinical trial evaluated the safety and immunogenicity of a synthetic DNA vaccine encoding the pre-membrane (prM) and E proteins of Zika (GLS-5700). GLS-5700 was administered via intradermal injection followed by electroporation, in a prime-boost regimen consisting of three doses of vaccine. The vaccine was tested in healthy, dengue-seronegative adults. Results from this trial showed that the DNA vaccine was well-tolerated and did not elicit any severe adverse effect in the volunteers. All participants developed ZIKV-binding antibody responses. Around $60 \%$ of participants developed ZIKV-neutralizing antibody response, but at low titers (1:18 to 1:317) and that did not correlate with vaccine dose. Participants also developed moderate T-cell response after vaccination. Importantly, this immune response was protective in both in vitro and in vivo (adoptive transfer) challenge models [82]. Another phase I trial designed to evaluate safety, tolerability, and immunogenicity of GLS-5700 in dengue-seropositive adults has been completed (NCT02887482), but results are yet to be published.

Results from two other phase I clinical trials assessing safety and immunogenicity of Zika DNA vaccine candidates were jointly published in late 2018 [81]. In these trials, two vaccine formulations were independently tested: one wild-type ZIKV DNA vaccine formulation (VRC 5283) and one chimera JEV/ZIKV DNA vaccine (VRC 5288). Both vaccine constructs express ZIKV E antigen (French Polynesian strain), but in the JEV/ZIKV chimera, the stem and transmembrane regions of the E protein of ZIKV were modified to encode JEV sequences. In addition, in both vaccines the prM was comprised of analogous sequence from JEV to improve particle secretion. No information about previous flavivirus profile of the volunteers was provided in these publications. Different vaccine doses and inoculation methods (intramuscularly using a needle syringe or a needle-free device) were tested (Table 2). Both DNA vaccine constructs were safe and well-tolerated and showed no severe adverse outcomes in healthy adult volunteers. VRC5283 showed the greatest immunogenicity given in split doses via needle-free injection All participants in the VRC5283 trial had detectable ZIKV antibody responses as well as ZIKV-neutralizing antibody, and showed CD4 and CD8 T-cell responses of the greatest magnitude when compared to VRC 5288 [81]. VRC5283 has advanced to an international placebo-controlled phase II trial. The efficacy of a three-dose $(0,4$, and 8 weeks) vaccination regimen of VRC5283 administered via needle-free delivery with the Stratis device (NCT03110770) is being assessed in adults and adolescents residing in flavivirus endemic and nonendemic areas.

\subsection{Purified, Inactivated Virus Vaccines}

Four different Zika inactivated vaccines have entered phase I clinical trials (Table 1): two of those have had their results recently published and the other two have completed phase I trial, but results are yet to be announced. In 2018, Modjarrad and colleagues [80] published the interim, aggregated results of three phase I clinical trials of a purified, formalin-inactivated Zika vaccine (ZPIV) (NCT02963909, NCT02952833, and NCT02937233). In these trials, healthy adults randomly received $5 \mu \mathrm{g}$ of either ZIPV with alum adjuvant or saline placebo intramuscularly at weeks 0 and 4 . All participants in these trials were initially reported to be flavivirus-naïve, but some participants were later found to be flavivirus positive in a post hoc analysis. ZPIV vaccine caused only minor to moderate reactogenicity. By day 57 of follow-up, more than $90 \%$ of the participants seroconverted to Zika neutralizing antibodies. However, $15 \%$ of those have geometric mean titers (GMT) lower than 100. Adoptive transfer of purified IgG collected at day 57 of follow-up provided robust protection against viremia in ZIKV-challenged mice [80].

In 2020, Stephenson and colleagues [79] published additional results for this vaccine in a trial comparing different doses and vaccination schedules of the ZPIV vaccine (NCT02937233). The focus of this trial was on vaccination schedule. In addition to testing a two-dose ZPIV schedule at weeks 0 and 4 , which is a standard regimen for purified inactivated flavivirus vaccines, authors also examined 
the safety and immunogenicity of a single-dose regimen and an accelerated two-dose regimen with ZPIV given at weeks 0 and 2. Volunteers have no known history of previous flavivirus infection or vaccination. High antibody titers were observed when using the standard dose regimen. However, at week 28 , a positive response was observed in only $13 \%$ of the participants who received ZPIV via the standard regimen $(n=8)$ and in none of the participants who received ZPIV via the accelerated $(n=7)$ or single-dose $(n=10)$ regimens (Table 2). Importantly, ZIKV-neutralizing antibody levels declined to a GMT of less than 100 by week 16. This short durability of antibody response is probably related to the lack of induction of robust $\mathrm{T}$ cell responses. Of note, the accelerated regimen elicited similar peak of ZIKV-neutralizing antibody titers when compared to the standard regimen, but this peak concentration was achieved sooner. However, the antibody response of both regimens was not durable [79]. Additional trials of the ZPIV vaccine have been completed and include testing two doses of ZPIV and a late ZPIV boost (NCT02963909), as well as higher ZPIV doses (NCT02952833) in healthy, flavivirus-naïve adult individuals. Another phase I trial is assessing ZPIV immunogenicity in healthy adults residing in a flavivirus endemic area (NCT03008122) (Table 1).

Recently, Han and colleagues [78] reported the results of a phase I clinical trial on the safety, dose ranging, and immunogenicity (NCT03343626) of a different purified, formalin-inactivated, alum-adjuvated whole Zika virus vaccine candidate (PIZV). So far, this is the first large phase I trial that compared vaccine immunogenicity in flavivirus-naïve versus flavivirus-primed volunteers (Table 2). Authors tested three doses $(2,5$, and $10 \mu \mathrm{g})$ of this vaccine formulation and all were reported to be safe and well-tolerated in healthy adults with and without preexisting exposure to other flaviviruses throughout 57 weeks of follow-up. A two-dose regimen of the vaccine administered 28 days apart elicited a robust, dose-dependent Zika virus-neutralizing antibody response in $100 \%$ of the flavivirus-naïve participants. Neutralizing antibody GMT among flavivirus-naïve individuals remained $>3000$ in the $10 \mu \mathrm{g}$ vaccine group by study week 57 . A similar dose-dependent neutralizing antibody response was also noted among flavivirus-primed volunteers, but GMTs did not increase following second dose and tended to be lower than those in the flavivirus-naïve group [78].

\section{3. mRNA Vaccines}

Two mRNA vaccine candidates, named mRNA-1325 (NCT03014089) and mRNA-1893 (NCT04064905), have entered phase I clinical trials (Table 1). These vaccine constructs incorporate $\mathrm{prM} / \mathrm{E}$ genes of ZIKV, but differ with respect to the signal peptide at the amino terminus of prM. mRNA-1325 expresses the signal sequence from human IgE upstream of prM [83]. Both vaccine constructs were immunogenic and protected against Zika infection in multiple mouse models. Interim phase I data for mRNA-1893 were press released in April 2020 by the sponsors (ModernaTX Inc., Cambridge, MA, United States) [84]. A two-dose (10 or $30 \mu \mathrm{g})$ vaccination schedule of mRNA-1893 given 28 days apart was well-tolerated in healthy adults with and without preexisting exposure to other flaviviruses. No serious vaccine-related adverse events were reported by volunteers. Both 10 and $30 \mu \mathrm{g}$ dose levels were immunogenic. All flavivirus-seronegative individuals seroconverted to Zika-neutralizing antibodies in the $30 \mu \mathrm{g}$ dose group after the second vaccination. In the group consisting of flavivirus-primed participants, $75 \%$ achieved a four-fold boost in preexisting neutralizing titers following a second vaccination at the $30 \mu \mathrm{g}$ dose. These results are yet to be published in peer-reviewed journals.

\subsection{Live Attenuated Vaccines}

Several strategies to develop a live-attenuated Zika vaccine have been employed, but despite promising preclinical data only one live-attenuated Zika vaccine candidate has entered phase I clinical trial so far (NCT03611946). Live-attenuated vaccine approaches include chimeric flavivirus constructs expressing ZIKV prM/E in the genetic background of YFV, JEV, or DENV [85-88] and nucleotide deletion in the $3^{\prime}$ UTR $[89,90]$. These vaccines have been proved immunogenic and protective in both mice and non-human primate models [85-90]. The live-attenuated chimeric rZIKV/D4D30-713 vaccine 
has completed phase I clinical trial in healthy, flavivirus-naïve adults (NCT03611946). This vaccine expresses ZIKV prM-E proteins in the genomic backbone of DENV-4 and encodes a 30-nucleotide deletion in the $3^{\prime}$ UTR to attenuate viral replication. Preclinical and phase I data on this vaccine have not yet been reported.

\subsection{Viral-Vectored Vaccines}

Different viral-vectored vaccines expressing ZIKV prM/E proteins have entered phase I clinical trials (Table 1). These viral vectors include adenovirus and measles vaccine virus as the delivery platform for ZIKV antigens. Preclinical evaluation of a recombinant measles Schwarz vaccine (MV-ZIKA) vector expressing ZIKV prM-E reduced plasma viremia and viral load in distinct organs and in the placenta, preventing fetal infection [91]. MV-ZIKA has completed phase I clinical trial, but results are yet to be published (NCT02996890). Another similar measles-based vaccine (MV-ZIKV-RSP) has entered phase I trials and the study is currently recruiting participants in Austria (NCT04033068). A replication-deficient vaccine candidate based on chimpanzee adenovirus (ChAdOx1) encoding ZIKV prM-E has also proved protective against ZIKV challenge in mice. This vaccine elicited long-lasting anti-envelope immunity in mice with no evidence of enhancement of dengue virus in vitro [92]. ChAdOx1 has entered two phase I clinical trials to determine its safety and immunogenicity in healthy adults when administered as a standalone vaccine or coadministered with a Chikungunya virus (CHIKV) vaccine (NCT04015648 and NCT04440774). Immunization with a replication-incompetent human adenovirus type 26 (AD26)-vectored vaccine encoding ZIKV M and E proteins (Ad26.ZIKV.001) induced robust ZIKV binding and neutralizing antibody responses as well as cellular responses in mice and non-human primates during preclinical evaluation [93]. A single dose of Ad26.ZIKV.001 provided full protection against Zika challenge in several mice models and non-human primates. This vaccine has advanced to phase I clinical trial (NCT03356561).

\section{Challenges in Late Stage Development of Zika Vaccines and Future Perspectives}

Despite the fast-paced start and promising phase I clinical trial results, several challenges for the late development of ZIKV vaccine candidates still remain. Further development of Zika vaccines will require efficacy studies in phase III trials and these trials face major challenges. Typical flavivirus vaccine efficacy trials require the detection of a large number of virologically confirmed cases and comparison of the number of cases or the viremia levels between immunized and control groups. However, in order to compensate for the high proportion of asymptomatic/unapparent ZIKV infections, these studies would need to enroll a relatively large number of volunteers as compared to dengue vaccine studies. In addition, following the explosive 2015/2016 outbreaks, ZIKV transmission has been dramatically reduced. Thus, in the context of low level of transmission rates, the number of volunteers required would increase even further, making the assessment of clinical vaccine efficacy even more difficult [94]. In addition, the ultimate goal of a Zika vaccine is the prevention of congenital disease; measuring this effect directly in a phase III trial would be extremely difficult and costly. Therefore, it is crucial to better characterize the pathogenic mechanisms involved in Zika congenital disease in order to identify and validate correlates of immunity to be employed in the evaluation of the efficacy of vaccine candidates. It is also critical to take into consideration the challenge of developing a business model to attract enough investment in order to continue developing a Zika vaccine and, subsequently, maintain a sustained production of it. As with several other newly emerging pathogens that have threatened human health on a global scale, efforts for vaccine development usually decline when the epidemic wanes. Robust public and private funding must continue to be provided if we are to support phase III clinical trials of Zika vaccine candidates. One possible strategy to reduce the cost of phase III trials would be to have the trials and study sites pre-planned and ready to start on short notice when a new outbreak emerges. 
Substantial concern also exists regarding the interactions between preexisting flavivirus immunity and the potential for vaccine-mediated ADE of disease. There has been a growing body of work supporting the idea that the balance between the concentration of cross-reactive antibodies at the time of infection and the interval between two infections are important factors influencing protection against or enhancement of flavivirus disease. In humans, enhancement of dengue disease has been shown to occur within a narrow range of preexisting DENV antibody concentration [95]. In Zika, high titers of preexisting DENV antibodies have been associated with protection against subsequent ZIKV infections in humans [58]. Recent evidence from experimental [59] and epidemiological [57] studies also suggests that low Zika antibody levels may affect clinical outcome of future dengue disease in humans by increasing the risk for severe dengue. How immunity to Zika vaccine candidates might shape future flavivirus epidemics needs to be addressed. Regardless of the platform, most candidates in phase I trials have focused on vaccine strategies targeting antigens (e.g., E and/or prM) that are known to elicit cross-reactive antibody responses. Ideal vaccine candidates should elicit a threshold of cross-reactive antibody concentration that is sufficient to effectively neutralize virus infection, thus providing protection and avoiding vaccine-mediated ADE effects. Of note, most phase I trials have tested the safety and immunogenicity of their vaccine candidates in naïve and previously exposed flavivirus individuals. Long-term analysis of the persistence of vaccine-elicited antibody response and interactions with other flavivirus will be critical to address potential risk for vaccine-mediate enhancement of subsequent flavivirus disease in humans. The possibility of vaccine-mediated enhancement of disease would require careful deployment of the eventual Zika vaccine to be performed only in the age groups with high DENV seroprevalence or only in individuals with a confirmed DENV infection.

Finally, an ideal Zika vaccine needs to be safe for at-risk populations, including women of childbearing age, pregnant women, young children, elderly, and immune-compromised individuals. To achieve such a broad population spectrum, multiple vaccine platforms may be required. In addition, a Zika vaccine should not induce Guillain-Barré-like neurological side effects or congenital malformations in fetuses. Most of the Zika vaccine candidates currently in human trials have been shown to protect fetus against ZIKV challenge and prevent neurological, placental, and testis damage from it in mice and non-human primate models, but if this will hold true in humans still needs to be determined in clinical trials.

\section{Concluding Remarks}

A number of Zika vaccine candidates have completed phase I trial and have been shown to be safe, well tolerated, and immunogenic in healthy adult volunteers. These viable Zika vaccine candidates should continue their development. ZIKV has become endemic and new cases of Zika congenital syndrome continue to be reported in endemic areas. It is very likely that we will face another large Zika epidemic in the next 10-15 years as herd immunity decay. Therefore, it is critical for Zika vaccine developers to be ready to activate phase III trials and ramp up vaccine production in case another epidemic emerges. Vaccine developers should also consider coordinating strategies to use Dengue and Zika vaccines to maximize the immunogenicity of both vaccines and to reduce the risks associated with deleterious DENV and ZIKV cross-reactive antibody interactions. Moreover, the coordinated use of both vaccines may also lead to a more attractive business model.

Author Contributions: P.M.S.C. and E.T.A.M. wrote the manuscript. All authors have read and agreed to the published version of the manuscript.

Funding: This research was funded by CuraZika Alliance Fund.

Conflicts of Interest: The authors declare no conflict of interest. The funders had no role in the design of the study; in the collection, analyses, or interpretation of data; in the writing of the manuscript, or in the decision to publish the results. 


\section{References}

1. Dick, G.W.; Kitchen, S.; Haddow, A. Zika Virus (I). Isolations and serological specificity. Trans. R. Soc. Trop. Med. Hyg. 1952, 46, 509-520. [CrossRef]

2. Vasilakis, N.; Weaver, S.C. Flavivirus transmission focusing on Zika. Curr. Opin. Virol. 2017, 22, 30-35. [CrossRef] [PubMed]

3. Filipe, A.R.; Martins, C.M.V.; Rocha, H. Laboratory infection with Zika virus after vaccination against yellow fever. Arch. Gesamte Virusforsch. 1973, 43, 315-319. [CrossRef] [PubMed]

4. Simpson, D. Zika virus infection in man. Trans. R. Soc. Trop. Med. Hyg. 1964, 58, 335-338. [CrossRef]

5. Kindhauser, M.K.; Allen, T.; Frank, V.; Santhana, R.S.; Dye, C. Zika: The origin and spread of a mosquito-borne virus. Bull. World Health Organ. 2016, 94, 675-686C. [CrossRef] [PubMed]

6. Duffy, M.R.; Chen, T.-H.; Hancock, W.T.; Powers, A.M.; Kool, J.L.; Lanciotti, R.S.; Pretrick, M.; Marfel, M.; Holzbauer, S.; Dubray, C.; et al. Zika Virus Outbreak on Yap Island, Federated States of Micronesia. N. Engl. J. Med. 2009, 360, 2536-2543. [CrossRef] [PubMed]

7. Musso, D.; Nilles, E.J.; Cao-Lormeau, V.-M. Rapid spread of emerging Zika virus in the Pacific area. Clin. Microbiol. Infect. 2014, 20, O595-O596. [CrossRef] [PubMed]

8. Musso, D.; Nhan, T.; Robin, E.; Roche, C.; Bierlaire, D.; Zisou, K.; Shan Yan, A.; Cao-Lormeau, V.; Broult, J. Potential for Zika virus transmission through blood transfusion demonstrated during an outbreak in French Polynesia, November 2013 to February 2014. Eurosurveillance 2014, 19, 20761. [CrossRef]

9. Cao-Lormeau, V.-M.; Musso, D. Emerging arboviruses in the Pacific. Lancet 2014, 384, 1571-1572. [CrossRef]

10. Campos, G.S.; Bandeira, A.C.; Sardi, S.I. Zika Virus Outbreak, Bahia, Brazil. Emerg. Infect. Dis. 2015, 21, 1885-1886. [CrossRef]

11. Zanluca, C.; De Melo, V.C.A.; Mosimann, A.L.P.; Dos Santos, G.I.V.; Dos Santos, C.N.D.; Luz, K. First report of autochthonous transmission of Zika virus in Brazil. Mem. Inst. Oswaldo Cruz 2015, 110, 569-572. [CrossRef] [PubMed]

12. Lowe, R.; Barcellos, C.; Brasil, P.; Cruz, O.; Honório, N.; Kuper, H.; Carvalho, M. The Zika Virus Epidemic in Brazil: From Discovery to Future Implications. Int. J. Environ. Res. Public Health 2018, 15, 96. [CrossRef] [PubMed]

13. Zhang, Q.; Sun, K.; Chinazzi, M.; Pastore y Piontti, A.; Dean, N.E.; Rojas, D.P.; Merler, S.; Mistry, D.; Poletti, P.; Rossi, L.; et al. Spread of Zika virus in the Americas. Proc. Natl. Acad. Sci. USA 2017, 114, E4334-E4343. [CrossRef] [PubMed]

14. Faria, N.R.; Quick, J.; Claro, I.M.; Thézé, J.; De Jesus, J.G.; Giovanetti, M.; Kraemer, M.U.G.; Hill, S.C.; Black, A.; Da Costa, A.C.; et al. Establishment and cryptic transmission of Zika virus in Brazil and the Americas. Nature 2017, 546, 406-410. [CrossRef]

15. Teixeira, M.G.; Da Conceição, N.; Costa, M.; De Oliveira, W.K.; Nunes, M.L.; Rodrigues, L.C. The Epidemic of Zika Virus-Related Microcephaly in Brazil: Detection, Control, Etiology, and Future Scenarios. Am. J. Public Health 2016, 106, 601-605. [CrossRef]

16. De Araújo, T.V.B.; Rodrigues, L.C.; De Alencar Ximenes, R.A.; De Barros Miranda-Filho, D.; Montarroyos, U.R.; De Melo, A.P.L.; Valongueiro, S.; De Albuquerque, M.D.F.P.M.; Souza, W.V.; Braga, C.; et al. Association between Zika virus infection and microcephaly in Brazil, January to May, 2016: Preliminary report of a case-control study. Lancet Infect. Dis. 2016, 16, 1356-1363. [CrossRef]

17. De Araújo, T.V.B.; Ximenes, R.A.D.A.; Miranda-Filho, D.D.B.; Souza, W.V.; Montarroyos, U.R.; De Melo, A.P.L.; Valongueiro, S.; De Albuquerque, M.D.F.P.M.; Braga, C.; Filho, S.P.B.; et al. Association between microcephaly, Zika virus infection, and other risk factors in Brazil: Final report of a case-control study. Lancet. Infect. Dis. 2018, 18, 328-336. [CrossRef]

18. World Health Organization WHO. Director-General summarizes the outcome of the Emergency Committee Regarding Clusters of Microcephaly and Guillain-Barré Syndrome. Available online: https://www.who.int/en/news-room/detail/01-02-2016-who-director-general-summarizes-the-outcome-ofthe-emergency-committee-regarding-clusters-of-microcephaly-and-guillain-barré-syndrome (accessed on 12 September 2020). 
19. Magalhaes, T.; Morais, C.N.L.; Jacques, I.J.A.A.; Azevedo, E.A.N.; Brito, A.M.; Lima, P.V.; Carvalho, G.M.M.; Lima, A.R.S.; Castanha, P.M.S.; Cordeiro, M.T.; et al. Follow-up household serosurvey in Northeast Brazil for Zika virus: Sexual contacts of index patients have the highest risk for seropositivity. J. Infect. Dis. 2020. [CrossRef]

20. Brooks, R.B.; Carlos, M.P.; Myers, R.A.; White, M.G.; Bobo-Lenoci, T.; Aplan, D.; Blythe, D.; Feldman, K.A. Likely Sexual Transmission of Zika Virus from a Man with No Symptoms of Infection-Maryland, 2016. MMWR. Morb. Mortal. Wkly. Rep. 2016, 65, 915-916. [CrossRef]

21. Fréour, T.; Mirallié, S.; Hubert, B.; Splingart, C.; Barrière, P.; Maquart, M.; Leparc-Goffart, I. Sexual transmission of Zika virus in an entirely asymptomatic couple returning from a Zika epidemic area, France, April 2016. Eurosurveillance 2016, 21, 30254. [CrossRef]

22. Davidson, A.; Slavinski, S.; Komoto, K.; Rakeman, J.; Weiss, D. Suspected Female-to-Male Sexual Transmission of Zika Virus-New York City, 2016. MMWR Morb. Mortal. Wkly. Rep. 2016, 65, 716-717. [CrossRef] [PubMed]

23. Deckard, D.T.; Chung, W.M.; Brooks, J.T.; Smith, J.C.; Woldai, S.; Hennessey, M.; Kwit, N.; Mead, P. Male-to-Male Sexual Transmission of Zika Virus-Texas, January 2016. MMWR Morb. Mortal. Wkly. Rep. 2016, 65, 372-374. [CrossRef] [PubMed]

24. Musso, D.; Roche, C.; Robin, E.; Nhan, T.; Teissier, A.; Cao-Lormeau, V.-M. Potential Sexual Transmission of Zika Virus. Emerg. Infect. Dis. 2015, 21, 359-361. [CrossRef] [PubMed]

25. Bhatnagar, J.; Rabeneck, D.B.; Martines, R.B.; Reagan-Steiner, S.; Ermias, Y.; Estetter, L.B.C.; Suzuki, T.; Ritter, J.; Keating, M.K.; Hale, G.; et al. Zika Virus RNA Replication and Persistence in Brain and Placental Tissue. Emerg. Infect. Dis. 2017, 23, 405-414. [CrossRef]

26. Miner, J.J.; Cao, B.; Govero, J.; Smith, A.M.; Fernandez, E.; Cabrera, O.H.; Garber, C.; Noll, M.; Klein, R.S.; Noguchi, K.K.; et al. Zika Virus Infection during Pregnancy in Mice Causes Placental Damage and Fetal Demise. Cell 2016, 165, 1081-1091. [CrossRef]

27. Quicke, K.M.; Bowen, J.R.; Johnson, E.L.; McDonald, C.E.; Ma, H.; O’Neal, J.T.; Rajakumar, A.; Wrammert, J.; Rimawi, B.H.; Pulendran, B.; et al. Zika Virus Infects Human Placental Macrophages. Cell Host Microbe 2016, 20, 83-90. [CrossRef]

28. Teixeira, F.M.E.; Pietrobon, A.J.; Oliveira, L.D.M.; Oliveira, L.M.D.S.; Sato, M.N. Maternal-Fetal Interplay in Zika Virus Infection and Adverse Perinatal Outcomes. Front. Immunol. 2020, 11. [CrossRef]

29. Microcephaly Epidemic Research Group. Microcephaly in Infants, Pernambuco State, Brazil, 2015. Emerg. Infect. Dis. 2016, 22, 1090-1093. [CrossRef]

30. Miranda-Filho, D.D.B.; Martelli, C.M.T.; Ximenes, R.A.d.A.; Araújo, T.V.B.; Rocha, M.A.W.; Ramos, R.C.F.; Dhalia, R.; França, R.F.d.O.; Marques Júnior, E.T.d.A.; Rodrigues, L.C. Initial Description of the Presumed Congenital Zika Syndrome. Am. J. Public Health 2016, 106, 598-600. [CrossRef]

31. Brasil, P.; Pereira, J.P.; Moreira, M.E.; Ribeiro Nogueira, R.M.; Damasceno, L.; Wakimoto, M.; Rabello, R.S.; Valderramos, S.G.; Halai, U.-A.; Salles, T.S.; et al. Zika Virus Infection in Pregnant Women in Rio de Janeiro. N. Engl. J. Med. 2016, 375, 2321-2334. [CrossRef]

32. Barjas-Castro, M.L.; Angerami, R.N.; Cunha, M.S.; Suzuki, A.; Nogueira, J.S.; Rocco, I.M.; Maeda, A.Y.; Vasami, F.G.S.; Katz, G.; Boin, I.F.S.F.; et al. Probable transfusion-transmitted Zika virus in Brazil. Transfusion 2016, 56, 1684-1688. [CrossRef] [PubMed]

33. Motta, I.J.F.; Spencer, B.R.; Cordeiro da Silva, S.G.; Arruda, M.B.; Dobbin, J.A.; Gonzaga, Y.B.M.; Arcuri, I.P.; Tavares, R.C.B.S.; Atta, E.H.; Fernandes, R.F.M.; et al. Evidence for Transmission of Zika Virus by Platelet Transfusion. N. Engl. J. Med. 2016, 375, 1101-1103. [CrossRef] [PubMed]

34. Méndez, N.; Oviedo-Pastrana, M.; Mattar, S.; Caicedo-Castro, I.; Arrieta, G. Zika virus disease, microcephaly and Guillain-Barré syndrome in Colombia: Epidemiological situation during 21 months of the Zika virus outbreak, 2015-2017. Arch. Public Heal. 2017, 75, 65. [CrossRef] [PubMed]

35. Barbi, L.; Coelho, A.V.C.; Alencar, L.C.A.d.; Crovella, S. Prevalence of Guillain-Barré syndrome among Zika virus infected cases: A systematic review and meta-analysis. Braz. J. Infect. Dis. 2018, 22, 137-141. [CrossRef]

36. Styczynski, A.R.; Malta, J.M.A.S.; Krow-Lucal, E.R.; Percio, J.; Nóbrega, M.E.; Vargas, A.; Lanzieri, T.M.; Leite, P.L.; Staples, J.E.; Fischer, M.X.; et al. Increased rates of Guillain-Barré syndrome associated with Zika virus outbreak in the Salvador metropolitan area, Brazil. PLoS Negl. Trop. Dis. 2017, 11, e0005869. [CrossRef] 
37. Rozé, B.; Najioullah, F.; Fergé, J.-L.; Apetse, K.; Brouste, Y.; Cesaire, R.; Fagour, C.; Fagour, L.; Hochedez, P.; Jeannin, S.; et al. Zika virus detection in urine from patients with Guillain-Barré syndrome on Martinique, January 2016. Eurosurveillance 2016, 21, 30154. [CrossRef]

38. Cao-Lormeau, V.-M.; Blake, A.; Mons, S.; Lastère, S.; Roche, C.; Vanhomwegen, J.; Dub, T.; Baudouin, L.; Teissier, A.; Larre, P.; et al. Guillain-Barré Syndrome outbreak associated with Zika virus infection in French Polynesia: A case-control study. Lancet 2016, 387, 1531-1539. [CrossRef]

39. De Siqueira, I.C.; Rodrigues, S.G.; Martins, L.C.; Vasilakis, N.; Novaes, M.A.C.; Alcântara, L.C.J.; Farias, D.S.; Do Rosário, M.S.; De Jesus, P.A.P.; Ko, A.I.; et al. Guillain-Barré Syndrome After Zika Virus Infection in Brazil. Am. J. Trop. Med. Hyg. 2016, 95, 1157-1160. [CrossRef]

40. Soto-Hernández, J.L.; Ponce de León Rosales, S.; Vargas Cañas, E.S.; Cárdenas, G.; Carrillo Loza, K.; Díaz-Quiñonez, J.A.; López-Martínez, I.; Jiménez-Corona, M.-E.; Ruiz-Matus, C.; Kuri Morales, P. Guillain-Barré Syndrome Associated With Zika Virus Infection: A Prospective Case Series From Mexico. Front. Neurol. 2019, 10. [CrossRef]

41. Cauchemez, S.; Besnard, M.; Bompard, P.; Dub, T.; Guillemette-Artur, P.; Eyrolle-Guignot, D.; Salje, H.; Van Kerkhove, M.D.; Abadie, V.; Garel, C.; et al. Association between Zika virus and microcephaly in French Polynesia, 2013-2015: A retrospective study. Lancet 2016, 387, 2125-2132. [CrossRef]

42. Cuevas, E.L.; Tong, V.T.; Rozo, N.; Valencia, D.; Pacheco, O.; Gilboa, S.M.; Mercado, M.; Renquist, C.M.; González, M.; Ailes, E.C.; et al. Preliminary Report of Microcephaly Potentially Associated with Zika Virus Infection During Pregnancy-Colombia, January-November 2016. MMWR Morb. Mortal. Wkly. Rep. 2016, 65, 1409-1413. [CrossRef] [PubMed]

43. Fitzgerald, B.; Boyle, C.; Honein, M.A. Birth Defects Potentially Related to Zika Virus Infection During Pregnancy in the United States. JAMA 2018, 319, 1195. [CrossRef] [PubMed]

44. Collins, M.H.; Zepeda, O.; Blette, B.; Jadi, R.; Morales, M.; Pérez, R.; Liou, G.-J.A.; Montoya-Cruz, M.; Harris, E.; Becker-Dreps, S.; et al. Serologic surveillance of maternal Zika infection in a prospective cohort in Leon, Nicaragua during the peak of the Zika epidemic. PLoS ONE 2020, 15, e0230692. [CrossRef] [PubMed]

45. Hoen, B.; Schaub, B.; Funk, A.L.; Ardillon, V.; Boullard, M.; Cabié, A.; Callier, C.; Carles, G.; Cassadou, S.; Césaire, R.; et al. Pregnancy Outcomes after ZIKV Infection in French Territories in the Americas. N. Engl. J. Med. 2018, 378, 985-994. [CrossRef] [PubMed]

46. Honein, M.A.; Dawson, A.L.; Petersen, E.E.; Jones, A.M.; Lee, E.H.; Yazdy, M.M.; Ahmad, N.; Macdonald, J.; Evert, N.; Bingham, A.; et al. Birth Defects Among Fetuses and Infants of US Women With Evidence of Possible Zika Virus Infection During Pregnancy. JAMA 2017, 317, 59. [CrossRef] [PubMed]

47. Leal, M.C.; Muniz, L.F.; Ferreira, T.S.A.; Santos, C.M.; Almeida, L.C.; Van Der Linden, V.; Ramos, R.C.F.; Rodrigues, L.C.; Neto, S.S.C. Hearing Loss in Infants with Microcephaly and Evidence of Congenital Zika Virus Infection-Brazil, November 2015-May 2016. MMWR Morb. Mortal. Wkly. Rep. 2016, 65, 917-919. [CrossRef]

48. De Paula Freitas, B.; De Oliveira Dias, J.R.; Prazeres, J.; Sacramento, G.A.; Ko, A.I.; Maia, M.; Belfort, R. Ocular Findings in Infants With Microcephaly Associated With Presumed Zika Virus Congenital Infection in Salvador, Brazil. JAMA Ophthalmol. 2016, 134, 529. [CrossRef]

49. Mulkey, S.B.; Arroyave-Wessel, M.; Peyton, C.; Bulas, D.I.; Fourzali, Y.; Jiang, J.; Russo, S.; McCarter, R.; Msall, M.E.; Du Plessis, A.J.; et al. Neurodevelopmental Abnormalities in Children with in Utero Zika Virus Exposure Without Congenital Zika Syndrome. JAMA Pediatr. 2020, 174, 269. [CrossRef]

50. Einspieler, C.; Utsch, F.; Brasil, P.; Panvequio Aizawa, C.Y.; Peyton, C.; Hydee Hasue, R.; Françoso Genovesi, F.; Damasceno, L.; Moreira, M.E.; Adachi, K.; et al. Association of Infants Exposed to Prenatal Zika Virus Infection with Their Clinical, Neurologic, and Developmental Status Evaluated via the General Movement Assessment Tool. JAMA Netw. Open 2019, 2, e187235. [CrossRef]

51. Morrison, T.E.; Diamond, M.S. Animal Models of Zika Virus Infection, Pathogenesis, and Immunity. J. Virol. 2017, 91. [CrossRef]

52. El Costa, H.; Gouilly, J.; Mansuy, J.-M.; Chen, Q.; Levy, C.; Cartron, G.; Veas, F.; Al-Daccak, R.; Izopet, J.; Jabrane-Ferrat, N. ZIKA virus reveals broad tissue and cell tropism during the first trimester of pregnancy. Sci. Rep. 2016, 6, 35296. [CrossRef] [PubMed]

53. Retallack, H.; Di Lullo, E.; Arias, C.; Knopp, K.A.; Laurie, M.T.; Sandoval-Espinosa, C.; Mancia Leon, W.R.; Krencik, R.; Ullian, E.M.; Spatazza, J.; et al. Zika virus cell tropism in the developing human brain and inhibition by azithromycin. Proc. Natl. Acad. Sci. USA 2016, 113, 14408-14413. [CrossRef] [PubMed] 
54. Leda, A.R.; Bertrand, L.; Andras, I.E.; El-Hage, N.; Nair, M.; Toborek, M. Selective Disruption of the Blood-Brain Barrier by Zika Virus. Front. Microbiol. 2019, 10. [CrossRef] [PubMed]

55. Brito, C.A.A.; Henriques-Souza, A.; Soares, C.R.P.; Castanha, P.M.S.; Machado, L.C.; Pereira, M.R.; Sobral, M.C.M.; Lucena-Araujo, A.R.; Wallau, G.L.; Franca, R.F.O. Persistent detection of Zika virus RNA from an infant with severe microcephaly-A case report. BMC Infect. Dis. 2018, 18, 388. [CrossRef] [PubMed]

56. Paz-Bailey, G.; Rosenberg, E.S.; Doyle, K.; Munoz-Jordan, J.; Santiago, G.A.; Klein, L.; Perez-Padilla, J.; Medina, F.A.; Waterman, S.H.; Adams, L.E.; et al. Persistence of Zika Virus in Body Fluids-Final Report. N. Engl. J. Med. 2018, 379, 1234-1243. [CrossRef]

57. Katzelnick, L.C.; Narvaez, C.; Arguello, S.; Lopez Mercado, B.; Collado, D.; Ampie, O.; Elizondo, D.; Miranda, T.; Bustos Carillo, F.; Mercado, J.C.; et al. Zika virus infection enhances future risk of severe dengue disease. Science 2020, 369, 1123-1128. [CrossRef]

58. Rodriguez-Barraquer, I.; Costa, F.; Nascimento, E.J.M.; Nery, N.; Castanha, P.M.S.; Sacramento, G.A.; Cruz, J.; Carvalho, M.; De Olivera, D.; Hagan, J.E.; et al. Impact of preexisting dengue immunity on Zika virus emergence in a dengue endemic region. Science 2019, 363, 607-610. [CrossRef]

59. Castanha, P.M.S.; Erdos, G.; Watkins, S.C.; Falo, L.D.; Marques, E.T.A.; Barratt-Boyes, S.M. Reciprocal immune enhancement of dengue and Zika virus infection in human skin. JCI Insight 2020, 5. [CrossRef]

60. George, J.; Valiant, W.G.; Mattapallil, M.J.; Walker, M.; Huang, Y.-J.S.; Vanlandingham, D.L.; Misamore, J.; Greenhouse, J.; Weiss, D.E.; Verthelyi, D.; et al. Prior Exposure to Zika Virus Significantly Enhances Peak Dengue-2 Viremia in Rhesus Macaques. Sci. Rep. 2017, 7, 10498. [CrossRef]

61. Kawiecki, A.B.; Christofferson, R.C. Zika Virus-Induced Antibody Response Enhances Dengue Virus Serotype 2 Replication in vitro. J. Infect. Dis. 2016, 214, 1357-1360. [CrossRef]

62. Castanha, P.M.S.; Nascimento, E.J.M.; Braga, C.; Cordeiro, M.T.; De Carvalho, O.V.; De Mendonça, L.R.; Azevedo, E.A.N.; França, R.F.O.; Dhalia, R.; Marques, E.T.A. Dengue Virus-Specific Antibodies Enhance Brazilian Zika Virus Infection. J. Infect. Dis. 2017, 215, 781-785. [CrossRef] [PubMed]

63. Bardina, S.V.; Bunduc, P.; Tripathi, S.; Duehr, J.; Frere, J.J.; Brown, J.A.; Nachbagauer, R.; Foster, G.A.; Krysztof, D.; Tortorella, D.; et al. Enhancement of Zika virus pathogenesis by preexisting antiflavivirus immunity. Science 2017, 356, 175-180. [CrossRef] [PubMed]

64. Fowler, A.M.; Tang, W.W.; Young, M.P.; Mamidi, A.; Viramontes, K.M.; McCauley, M.D.; Carlin, A.F.; Schooley, R.T.; Swanstrom, J.; Baric, R.S.; et al. Maternally Acquired Zika Antibodies Enhance Dengue Disease Severity in Mice. Cell Host Microbe 2018, 24, 743-750.e5. [CrossRef] [PubMed]

65. Priyamvada, L.; Quicke, K.M.; Hudson, W.H.; Onlamoon, N.; Sewatanon, J.; Edupuganti, S.; Pattanapanyasat, K.; Chokephaibulkit, K.; Mulligan, M.J.; Wilson, P.C.; et al. Human antibody responses after dengue virus infection are highly cross-reactive to Zika virus. Proc. Natl. Acad. Sci. USA 2016, 113, 7852-7857. [CrossRef] [PubMed]

66. Collins, M.H.; Metz, S.W. Progress and Works in Progress: Update on Flavivirus Vaccine Development. Clin. Ther. 2017, 39, 1519-1536. [CrossRef]

67. Deng, S.-Q.; Yang, X.; Wei, Y.; Chen, J.-T.; Wang, X.-J.; Peng, H.-J. A Review on Dengue Vaccine Development. Vaccines 2020, 8, 63. [CrossRef]

68. Sridhar, S.; Luedtke, A.; Langevin, E.; Zhu, M.; Bonaparte, M.; Machabert, T.; Savarino, S.; Zambrano, B.; Moureau, A.; Khromava, A.; et al. Effect of Dengue Serostatus on Dengue Vaccine Safety and Efficacy. N. Engl. J. Med. 2018, 379, 327-340. [CrossRef]

69. World Health Organization. Zika Vaccine Development Technology Roadmap. Available online: https://www.who.int/immunization/research/development/Zika_Vaccine_Development_Technology_Ro admap_after_consultation_April_2019.pdf?ua=1 (accessed on 14 September 2020).

70. Vartak, A.; Sucheck, S. Recent Advances in Subunit Vaccine Carriers. Vaccines 2016, 4, 12. [CrossRef]

71. Wallis, J.; Shenton, D.P.; Carlisle, R.C. Novel approaches for the design, delivery and administration of vaccine technologies. Clin. Exp. Immunol. 2019, cei.13287. [CrossRef]

72. Cabral-Miranda, G.; Lim, S.M.; Mohsen, M.O.; Pobelov, I.V.; Roesti, E.S.; Heath, M.D.; Skinner, M.A.; Kramer, M.F.; Martina, B.E.E.; Bachmann, M.F. Zika Virus-Derived E-DIII Protein Displayed on Immunologically Optimized VLPs Induces Neutralizing Antibodies without Causing Enhancement of Dengue Virus Infection. Vaccines 2019, 7, 72. [CrossRef] 
73. Yang, M.; Lai, H.; Sun, H.; Chen, Q. Virus-like particles that display Zika virus envelope protein domain III induce potent neutralizing immune responses in mice. Sci. Rep. 2017, 7, 7679. [CrossRef] [PubMed]

74. Garg, H.; Mehmetoglu-Gurbuz, T.; Joshi, A. Virus Like Particles (VLP) as multivalent vaccine candidate against Chikungunya, Japanese Encephalitis, Yellow Fever and Zika Virus. Sci. Rep. 2020, 10, 4017. [CrossRef] [PubMed]

75. Liu, A. Comparison of Plasmid DNA and mRNA as Vaccine Technologies. Vaccines 2019, 7, 37. [CrossRef] [PubMed]

76. Marques, E.T.A.; Chikhlikar, P.; De Arruda, L.B.; Leao, I.C.; Lu, Y.; Wong, J.; Chen, J.-S.; Byrne, B.; August, J.T. HIV-1 p55Gag encoded in the lysosome-associated membrane protein-1 as a DNA plasmid vaccine chimera is highly expressed, traffics to the major histocompatibility class II compartment, and elicits enhanced immune responses. J. Biol. Chem. 2003, 278, 37926-37936. [CrossRef]

77. Arruda, L.B.; Sim, D.; Chikhlikar, P.R.; Maciel, M.; Akasaki, K.; August, J.T.; Marques, E.T.A. Dendritic cell-lysosomal-associated membrane protein (LAMP) and LAMP-1-HIV-1 gag chimeras have distinct cellular trafficking pathways and prime $\mathrm{T}$ and $\mathrm{B}$ cell responses to a diverse repertoire of epitopes. J. Immunol. 2006, 177, 2265-2275. [CrossRef]

78. Han, H.-H.; Diaz, C.; Acosta, C.; Liu, M.; Borkowski, A. Safety and immunogenicity of a purified inactivated Zika virus vaccine (PIZV) candidate in healthy adults; A randomised, observer-blind phase 1 clinical trial. Lancet Infect. Dis.. in press.

79. Stephenson, K.E.; Tan, C.S.; Walsh, S.R.; Hale, A.; Ansel, J.L.; Kanjilal, D.G.; Jaegle, K.; Peter, L.; Borducchi, E.N.; Nkolola, J.P.; et al. Safety and immunogenicity of a Zika purified inactivated virus vaccine given via standard, accelerated, or shortened schedules: A single-centre, double-blind, sequential-group, randomised, placebo-controlled, phase 1 trial. Lancet Infect. Dis. 2020, 20, 1061-1070. [CrossRef]

80. Modjarrad, K.; Lin, L.; George, S.L.; Stephenson, K.E.; Eckels, K.H.; De La Barrera, R.A.; Jarman, R.G.; Sondergaard, E.; Tennant, J.; Ansel, J.L.; et al. Preliminary aggregate safety and immunogenicity results from three trials of a purified inactivated Zika virus vaccine candidate: Phase 1, randomised, double-blind, placebo-controlled clinical trials. Lancet 2018, 391, 563-571. [CrossRef]

81. Gaudinski, M.R.; Houser, K.V.; Morabito, K.M.; Hu, Z.; Yamshchikov, G.; Rothwell, R.S.; Berkowitz, N.; Mendoza, F.; Saunders, J.G.; Novik, L.; et al. Safety, tolerability, and immunogenicity of two Zika virus DNA vaccine candidates in healthy adults: Randomised, open-label, phase 1 clinical trials. Lancet 2018, 391, 552-562. [CrossRef]

82. Tebas, P.; Roberts, C.C.; Muthumani, K.; Reuschel, E.; White, S.; Khan, A.S.; Racine, T.; Choi, H.; Zaidi, F.; Boyer, J.; et al. ZIKA-001: Safety and Immunogenicity of an Engineered DNA Vaccine Against ZIKA virus infection. Open Forum Infect. Dis. 2017, 4, S300-S301. [CrossRef]

83. Richner, J.M.; Himansu, S.; Dowd, K.A.; Butler, S.L.; Salazar, V.; Fox, J.M.; Julander, J.G.; Tang, W.W.; Shresta, S.; Pierson, T.C.; et al. Modified mRNA Vaccines Protect against Zika Virus Infection. Cell 2017, 168, 1114-1125.e10. [CrossRef]

84. Moderna, T.X. Moderna Highlights Opportunity of mRNA Vaccines at Its First Vaccines Day. Available online: https://investors.modernatx.com/news-releases/news-release-details/moderna-highlights-opport unity-mrna-vaccines-its-first-vaccines (accessed on 10 September 2020).

85. Annamalai, A.S.; Pattnaik, A.; Sahoo, B.R.; Muthukrishnan, E.; Natarajan, S.K.; Steffen, D.; Vu, H.L.X.; Delhon, G.; Osorio, F.A.; Petro, T.M.; et al. Zika Virus Encoding Nonglycosylated Envelope Protein Is Attenuated and Defective in Neuroinvasion. J. Virol. 2017, 91. [CrossRef] [PubMed]

86. Annamalai, A.S.; Pattnaik, A.; Sahoo, B.R.; Guinn, Z.P.; Bullard, B.L.; Weaver, E.A.; Steffen, D.; Natarajan, S.K.; Petro, T.M.; Pattnaik, A.K. An Attenuated Zika Virus Encoding Non-Glycosylated Envelope (E) and Non-Structural Protein 1 (NS1) Confers Complete Protection against Lethal Challenge in a Mouse Model. Vaccines 2019, 7, 112. [CrossRef] [PubMed]

87. Xie, X.; Kum, D.B.; Xia, H.; Luo, H.; Shan, C.; Zou, J.; Muruato, A.E.; Medeiros, D.B.A.; Nunes, B.T.D.; Dallmeier, K.; et al. A Single-Dose Live-Attenuated Zika Virus Vaccine with Controlled Infection Rounds that Protects against Vertical Transmission. Cell Host Microbe 2018, 24, 487-499.e5. [CrossRef] [PubMed]

88. Li, X.-F.; Dong, H.-L.; Wang, H.-J.; Huang, X.-Y.; Qiu, Y.-F.; Ji, X.; Ye, Q.; Li, C.; Liu, Y.; Deng, Y.-Q.; et al. Development of a chimeric Zika vaccine using a licensed live-attenuated flavivirus vaccine as backbone. Nat. Commun. 2018, 9, 673. [CrossRef] 
89. Shan, C.; Muruato, A.E.; Jagger, B.W.; Richner, J.; Nunes, B.T.D.; Medeiros, D.B.A.; Xie, X.; Nunes, J.G.C.; Morabito, K.M.; Kong, W.-P.; et al. A single-dose live-attenuated vaccine prevents Zika virus pregnancy transmission and testis damage. Nat. Commun. 2017, 8, 676. [CrossRef]

90. Shan, C.; Muruato, A.E.; Nunes, B.T.D.; Luo, H.; Xie, X.; Medeiros, D.B.A.; Wakamiya, M.; Tesh, R.B.; Barrett, A.D.; Wang, T.; et al. A live-attenuated Zika virus vaccine candidate induces sterilizing immunity in mouse models. Nat. Med. 2017, 23, 763-767. [CrossRef]

91. Nürnberger, C.; Bodmer, B.S.; Fiedler, A.H.; Gabriel, G.; Mühlebach, M.D. A Measles Virus-Based Vaccine Candidate Mediates Protection against Zika Virus in an Allogeneic Mouse Pregnancy. Model. J. Virol. 2018, 93. [CrossRef]

92. López-Camacho, C.; Abbink, P.; Larocca, R.A.; Dejnirattisai, W.; Boyd, M.; Badamchi-Zadeh, A.; Wallace, Z.R.; Doig, J.; Velazquez, R.S.; Neto, R.D.L.; et al. Rational Zika vaccine design via the modulation of antigen membrane anchors in chimpanzee adenoviral vectors. Nat. Commun. 2018, 9, 2441. [CrossRef]

93. Cox, F.; Van Der Fits, L.; Abbink, P.; Larocca, R.A.; Van Huizen, E.; Saeland, E.; Verhagen, J.; Peterson, R.; Tolboom, J.; Kaufmann, B.; et al. Adenoviral vector type 26 encoding Zika virus (ZIKV) M-Env antigen induces humoral and cellular immune responses and protects mice and nonhuman primates against ZIKV challenge. PLoS ONE 2018, 13, e0202820. [CrossRef]

94. Vannice, K.S.; Cassetti, M.C.; Eisinger, R.W.; Hombach, J.; Knezevic, I.; Marston, H.D.; Wilder-Smith, A.; Cavaleri, M.; Krause, P.R. Demonstrating vaccine effectiveness during a waning epidemic: A WHO/NIH meeting report on approaches to development and licensure of Zika vaccine candidates. Vaccine 2019, 37, 863-868. [CrossRef] [PubMed]

95. Katzelnick, L.C.; Gresh, L.; Halloran, M.E.; Mercado, J.C.; Kuan, G.; Gordon, A.; Balmaseda, A.; Harris, E. Antibody-dependent enhancement of severe dengue disease in humans. Science 2017, 358, 929-932. [CrossRef] [PubMed]

Publisher's Note: MDPI stays neutral with regard to jurisdictional claims in published maps and institutional affiliations.

(C) 2020 by the authors. Licensee MDPI, Basel, Switzerland. This article is an open access article distributed under the terms and conditions of the Creative Commons Attribution (CC BY) license (http://creativecommons.org/licenses/by/4.0/). 